\title{
The Mediation of Tourists Satisfaction on the Relationship between Tourism Service Quality and Tourists Loyalty: Five Stars Hotel in Jordanian Environment
}

\author{
Ramzi M. Alrousan ${ }^{1} \&$ Ismaiel M. Abuamoud ${ }^{1}$ \\ ${ }^{1}$ Dept. of sustainable Tourism, Queen Rania Institute of Tourism and Heritage (QRITH), The Hashemite \\ University
}

Correspondence: Ramzi M. Alrousan, Dept. of sustainable Tourism, Queen Rania Institute of Tourism and Heritage (QRITH) The Hashemite University, Zarga, Jordan. Tel: 962-5-390-3333 Ext 4731. E-mail: rousanramzi@yahoo.com

Received: April 27, 2013

Accepted: July 8, 2013

Online Published: July 26, 2013

doi:10.5539/ ibr.v6n8p79

URL: http://dx.doi.org/10.5539/ ibr.v6n8p79

\begin{abstract}
This paper aims to examine the relationship between tourism service quality, tourism loyalty and tourism satisfaction expectations in hotel industry. In this paper, the service quality standard model has been used for evaluation of service quality, Parasuraman, Zeithaml, \& Berry (1985, 1988). Fornell et al. (1996) and Oh (2000) models with revision was used for evaluating the loyalty, and the instrument presented by Cauana, Money, and Berthon (2000) was used for evaluation of customer satisfaction. The focus of this research is five stars hotels in Jordan, and 322 customers of these hotels were sampled. The results of this paper demonstrate that in all aspects, customers' expectation, are higher than their perceptions of the hotels services. In addition, this research findings show that customer satisfaction plays the role of a mediator in the effects of service quality on service loyalty. Moreover, the findings of this study provide tourism professionals in Jordan with more insight about the idea of TSQ and help them improve the quality of their services.
\end{abstract}

Keywords: service quality, tourism, customer satisfaction, loyalty, Marriott

\section{Introduction}

The importance of tourism is highlighted through its role via revenue and foreign exchange, a preserver of cultures and historical heritage, a promoter of national development and a vital and crucial factor of employment opportunities. Where tourism is concerned, hotels are the first concern of all tourists. In Jordan, tourism is ever growing and customers are becoming more demanding (Alrousan, 2010). They demand for better services and start to demand for (TSQ). This is because Hotel service quality (TSQ) has been attracting the attention of customers and stakeholders in the face of global warming and increasing awareness towards the importance of protecting the global environment. Studies pertaining to hotels and TSQ in Jordan are rather rare and it is hoped that this study will add to the literature.

The link between service actions and service quality has verified its importance in marketing (Heskett $\&$ Sasser, 2010; Hutchinson, Lai \& Wang, 2009). In the past decades, the notions of service quality and service satisfaction have been greatly regarded and broadly used in marketing texts and activities. The benefits of satisfaction and quality have been admired by marketing researchers, who have viewed them as indices of an organization competitive benefit (Ruyter, 1997). Service loyalty, on the other hand, is one significant structure in service marketing, whose significance stems from its last effect on customers' repeated purchases. In fact, those loyal customers who purchase frequently are considered the starting point of any business (Caruana, 2002). Even though these concepts have been used in the marketing literature, but the link between these three concepts still remain unclear. Therefore, this research intends to study the relation of these three concepts.

\section{Literature Review}

\subsection{Service Quality in the Hotel Industry}

Even though SERVQUAL (Parasuraman et al., 1985; 1988) has been established for more than 10 years, it is puzzling that tourists satisfaction research and service quality measurement research in the hotel industry are still 
lacking both in depth and width (Tsang \& Qu, 2000; Akababa, 2006; Wilkins, Merrilees \& Herington, 2007). Getty and Thompson (1994) developed a specific application for quality research in the hotel industry, named LODGQUAL as a derivative of SERVQUAL and they used similar dimensions in their study. It focused on 45 percent of overall quality using a sample of hospitality students and the authors are confident that their findings could be used as a benchmark for measuring hotel performance.

Tsang and Qu (2000) evaluated service quality in China from tourist and hotel manager's perspective. They employed a modified version of the SERVQUAL model and they consistently identified the underperformance of hotels (except for one out of 35 questions), with the most significant aspects relating to cleanliness, room quality, staff performance, and prices. Two extremes were noted where the hotel managers consistently overestimated the tourists' expectations but generally underestimated the tourists' perception of service quality.

In summary, the limited amount of literature on service quality in the hotel industry hinders the development of many generalizations (Briggs, Sutherland \& Drummond, 2007; Tsaur \& Lin, 2004; Hudson, Hudson \& Miller, 2004). With regard to service quality, three studies that utilized some derivations of SERVQUAL were identified. In their study, Saleh and Ryan (1991) maintained that the SERVQUAL dimensions did not apply to the hotel industry. Consequently, Getty (1994) proposed an amended version of SERVQUAL, called LODGQUAL, and alternately. Tsang and Qu (2000) applied SERVQUAL but avoided any comment on the use of the measure, and instead believed that "the study attempted neither to test existing theory nor to develop new research instruments" (Tsang \& Qu, 2000. pg. 323). Other studies on service quality in the hotel industry compared business travelers in two locations, but only focused on a small number of respondents (Callan \& Kyndt, 2001), and mature travelers (Callan \& Bowman, 2000). Therefore, the lack of previous research on service quality in hotels, even when combined with the work on customer satisfaction, results in many aspects of hotel performance being left behind, unanswered.

\subsection{Loyalty Research in the Hotel Industry}

Since the hotel industry is highly competitive in nature, while there is a lack of substantive differentiation within any hotel quality grading, it is imperative that the issue of consumer loyalty is significant. More recently, in the broader marketing arena, the issues associated with consumer loyalty in a hospitality context have received an increased attention and focus both by related researchers and industry players bent on capturing a bigger slice of the industry. Despite the increased attention, specifically research on loyalty within a service context is still comparatively low (Javalgi \& Moberg, 1997; Kandompully \& Suhartanto, 2003; Chen McCain, Jang \& Hu, 2005), and the number of specific research on consumer choice and loyalty in the hospitality context are equally lacking in number and depths (Slattery, 2003).

Many researchers often assumed that loyalty is inferred from assessments of the factors consumers rated as important in selection. As such, it is implied that the main factor encouraging customer loyalty depends on resourcing those attributes that influences customers' choices (Slattery, 2003). However, despite the limited number of research in the area of customer loyalty (Kandompully \& Suhartanto, 2003), the importance of loyalty (Bowen \& Chen, 2001; Tepeci, 1999). An analysis of current hospitality research undertaken has shown inconsistencies in the focus and findings, with some researchers discovering no significant relationship between service quality and repurchase intentions (Cronin \& Taylor, 1992; Skogland \& Siguaw, 2004). In contrast, Boulding, Kaira, Staelin and Zeitham (1993) found a significant relationship between service qualities and repurchase intentions. Another research has indicated a threshold relationship with very high levels of satisfaction having a substantial impact on the levels of loyalty (Bowen \& Chen, 2001). This is with implications about the need for customers to enjoy the service provided so as to generate loyalty (Finn, 2005).

Of the existing studies in the hotel industry which looked at customer satisfaction, only a limited number have extended beyond this and studied the impact on loyalty. Of these, three studies were carried out in the United States and one in New Zealand. The findings of all three studies showed some substantial difference in results. In one of the studies conducted in the United States the findings included the importance of the quality of on-site services, personnel, guest room design and amenities (Dube \& Renaghan, 1999a), room upgrades, flexible check in-out and customized services (Bowen \& Shoemaker, 1998). In the other study, Barsky and Nash (2002) found distinct groups of affective emotions influencing loyalty. Alternatively, the New Zealand study discovered that the factors influencing loyalty included hotel image and customer satisfaction with reception, housekeeping, food and beverage and price but only housekeeping showed significance. Other researchers opined that housekeeping and hotel image were the most important factors in determining loyalty (Kandampully \& Suhartanto, 2000). In addition, the use of loyalty schemes has also prompted other researchers to suggest hotels generate spurious rather than true loyalty (Baloglu, 2002; Javalgi \& Moberg, 1997). 


\subsection{Customer Satisfaction in the Hotel Industry}

Studies pertaining to customer satisfaction in hotels (Barsky \& Labagh, 1992; Choi \& Chu, 2000; Gunderson, Heide \& Olsson, 1996) show much variety in their focus and findings. Two studies from the United States, one Norwegian and another from Hong Kong showed much variance in their results. The Norwegian study initiated by Gunderson et al. (1996) reported that both the intangible elements of reception and food and beverage, and the tangible aspect of housekeeping were significant, explaining eighty percent of the variance in satisfaction. They also discovered that the combined model of tangible and intangible aspects provided less clarity as there was an overlap between the non-significance of the tangible elements of food and beverage and reception, and the intangible aspects of housekeeping (Luck \& Lancaster, 2003).

In a US based study, Barsky and Labagh (1992) concluded that employee attitude was the most important contributor of customer satisfaction, followed by locations, room, price, facilities, reception, services, parking and food and beverage. In their study, based on a survey of restaurant and hotel managers pertaining to the causes of compliments and complaints. On the other hand, price, speed and quality of service, parking and poor employee knowledge resulted in negative feedbacks (Lewis \& McCann 2004). In Hong-Kong, Choi and Chu (2000) and Torres and Kline (2006) researched on a comparison of the satisfaction levels between Asian and Western travelers. Using a regression analysis of Asian and Western travelers' overall satisfaction, they discovered that in terms of customer satisfaction, Asian travelers placed the most importance on value as compared to Western travelers who considered room quality as the most important criteria for their satisfaction.

Overall, the numbers of researches which have addressed customer satisfaction in the hotel industry in isolation are rather limited (Choi \& Chu 2001). There are existing researches which have incorporated different research approaches and, although there some elements of similarity in the findings. Akababa (2006) found in the hotel in turkey, the substantive differences between the approaches used would reduce the possibility of similarity.

\section{The Conceptual Model of the Research}

Following conceptual model has been used in this article.

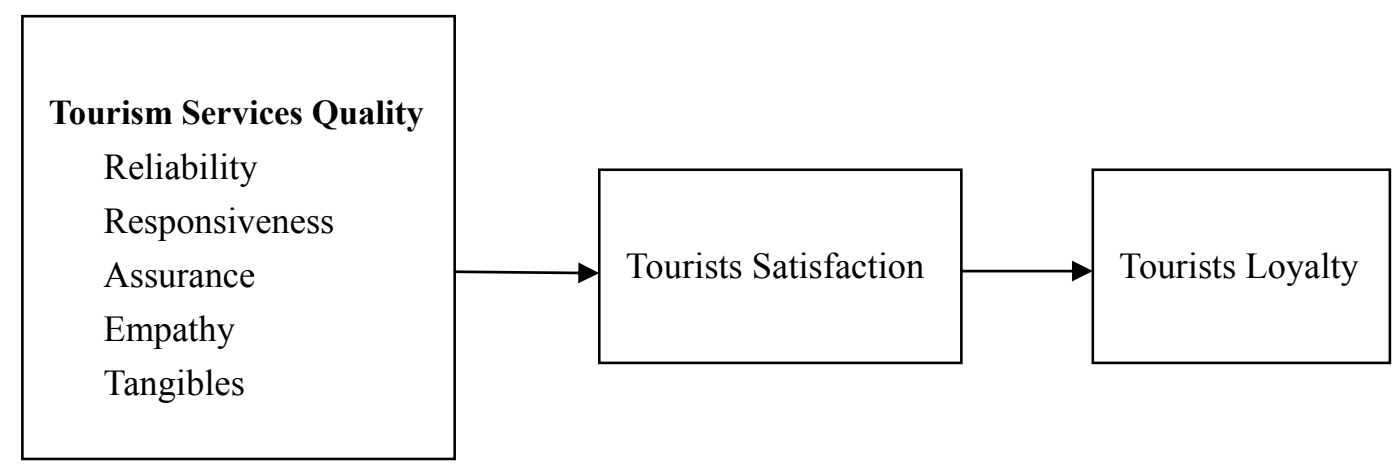

Figure 1. Research conceptual framework

\section{The Research Hypothesis}

Based on the proposed theoretical framework, several hypotheses were developed in order to investigate the relationship between tourism service quality on the tourist's satisfaction and customer loyalty. Specific hypothesis were developed to test the mediating role of tourists satisfaction on the relationship between tourism service quality and tourists loyalty.

\subsection{Service Quality and Tourist Satisfaction}

Several studies illustrated a positive relation between service quality and customer satisfaction. The findings of previous studies have shown that service quality often leads to customer satisfaction (Bitner \& Hubert, 1994; Fornel et al., 1996; Sivadas \& Bakereprewit, 2000; Zenithal, Berry, \& Parasuraman, 1996; Mentzer, Flint, \& Hunt, 2001). Oliver (1997) claims that when tourists experience service attributes of high quality, they are likely to experience higher levels of satisfaction with the service. On the other hand, if a customer was to experience any service quality which is lower than expected, then the satisfaction level will drop. Therefore, this hypothesis proposed that and increase or decrease in service quality would increase or decrease customer satisfaction in 
tandem with the changes.

In the case of the chain of Marriott hotels, international tourist often demand or request for high levels of service quality. This suggests that when excellent service quality is provided, the involved international hotel guests will surely be satisfied. That is, once their desires and needs for high level service quality are met, then it may lead to customer satisfaction. Thus, the first hypothesis reads as:

Hypothesis 1: There is a positive relationship between service quality provided by Marriott hotel chains in Jordan and its tourist's satisfaction.

\subsection{Tourists Satisfaction and Tourists Loyalty}

It has been argued that a positive service encounter would lead to the building of customer service relationship. A series of positive encounters will definitely improve customer satisfaction, trust and relation commitment (Morgan \& Hunt, 1994). In practice, satisfaction is an outcome of a purchase or a consumption of a service. As such, satisfaction is expected to influence loyalty at an increasing rate. However, some opposing studies suggested that the relationship between satisfaction and loyalty is non-linear (Oliva, Oliver, \& MacMillan, 1992) and consequently satisfaction does not ensure customer loyalty (Jones \& Sasser, 1995). Therefore, this research tests whether there is a positive relationship between customer satisfaction and customer loyalty.

When the international guests at the Marriott hotels have any needs, they usually forward their request to the front desk. Here, the responsibility of the officers at the front desk is very crucial as the type of service encounter by the international guests will have a bearing on their satisfaction. By ensuring that the international guests experience a series of positive encounters, the guests will trust the hotel and this leads to an increase in the satisfaction. As their satisfaction is enhanced, the result will be a high level of customer loyalty. Therefore, the second hypothesis is as follows.

Hypothesis2: There is a positive relationship between Tourists satisfaction of guests of Marriott hotel chains in Jordan and their loyalty to the hotel.

\subsection{Tourism Service Quality and Tourists Loyalty}

In the tourism sector, service quality has two aspects (Maltz \& Maltz, 1998) in the form of vital service quality and responsiveness. The first is vital service quality, and it involves cycle time, on-time delivery, and inventory availability. The second aspect is responsiveness, which is how an individual customer's needs are solved beyond traditional service measure (Davis \& Mandrodt, 1996). Service quality measures the extent to which delivered services match customers' expectations. Delivery service quality refers to meeting and satisfying customers' expectation every time and completely. Thus, this study examines whether a positive relationship between service quality and tourists loyalty exists or not.

Normally the international guests expect a high level of service quality. Here, the managers in Marriott hotel in Jordan and hoteliers must remember that what the guests seek for might also be offered by other adjacent hotels. As such, by being aware of the competition, the hotel concerned must ensure that the service quality is not only the best at all times but also must be consistently provided for all its guests. As a result from this best service quality guarantee, the international guests are likely to become loyal customers. Consequently, this leads to the third hypothesis as illustrated below.

Hypothesis 3: There is a positive relationship between Tourism Service Quality provided by Marriot Hotel chains in Jordan and its Tourists Loyalty.

\subsection{Mediating Role of Customer Satisfaction on the Relationship between Tourism Service Quality and Tourists Loyalty}

The literature discussed above has confirmed that service quality strongly influence customer loyalty by providing and maintaining customer satisfaction (Caruana, 2002; Fornell, Johnson, Anderson, Cha, \& Bryant, 1996). On the contrary, some researches were of the opinion that perceived service quality can pose a direct impact on behavioral outcomes in the absence of the satisfaction factor (Zethaml, 1998). Oliver (1997) disagreed with this satisfaction absence theory and instead suggested that satisfaction is "potentially all salient dimensions" and found that quality is the antecedent of satisfaction instead. A study done by Andreas and Wolfgang (2002) supported the idea posited by Oliver (1997) as they found that perceived value is a complement and not a substitute of satisfaction. They even claimed that customer satisfaction could strongly predict customer loyalty since customer satisfaction is ultimately measured against how far the perceived value is provided or offered to them. Hence, this study proposed that the relationship of tourism service quality is mediated by satisfaction.

With regard to international guests staying at the Marriott hotels in Jordan, it is evident that customer satisfaction 
is influenced by service quality. In the views of the international guests, they would prefer to continue using or to repeat the use of the same hotel's services when they are satisfied with the service quality offered or delivered by the hotel. This notion of delivering the perceived value is a true measure of the satisfaction which ultimately leads to customer loyalty. Hence, the fourth and last hypothesis is:

Hypothesis 4: Satisfaction among Tourists of Marriot Hotel chains in Jordan Mediates the Effect of Tourism Service Quality on Tourists Loyalty.

\section{Methodology}

In this study, a self-administered questionnaire, which is an adapted version of SERVQUAL scale, was used to measure TSQ of the hotel guests. The questionnaire consisted of four parts. The first part contained questions about socio-demographic data of the respondents. The second part was designed to measure the respondents' perceptions about the quality of services offered by the hotels. Based on questionnaire instruments developed in previous studies, 23 service quality items were developed. The third part of the questionnaire focused on assessing the respondents' perceptions regarding satisfaction on the same five-point scale, where seven tourists' satisfaction items were developed. The final part of the questionnaire assessed the tourist's perceptions regarding their loyalty. The instrument of measurement was introduced in a way that the topic of the study and procedures of response were briefly illustrated.

The measurement grades were used according to the five-point Likert scale (Malhotra, 2003). The grades were ordered regressively as follows: strongly agree (5), agree (4), neutral (3), disagree (2) and strongly disagree (1).

The present study was carried out in three different branches of the Marriot Hotel chain located in three different Jordanian cities. The population of this study comprised tourists who stayed in all three branches of the Marriot Hotel. Convenience sampling was employed, in which 322 questionnaires were distributed to the guests, who completed the questionnaires in the presence of the researchers. Then, the completed questionnaires were immediately collected by the researchers. In order to analyze the data, the Statistical Package for the Social Sciences (SPSS) version 16.0 was used. Descriptive statistics analysis was also used to measure customers' perception scores. Factor analysis was performed to explore the dimensionality of the 23 -item scale. Validity and reliability of the adapted scale were established.

\section{Data Analysis}

\subsection{Regression Analysis}

The independent variable that tourism service quality can explain $60 \%(\mathrm{R} 2=.60)$ of variance towards customer satisfaction is in Table 5.15 . The $40 \%$ due to error or explain by other factor is not included in this study. $\mathrm{R}$ squared is the proportion of variation in the dependent variable explained by the regression model. The values of $\mathrm{R}$ squared range from 0 to 1 . Small values indicate that the model does not fit the data well. $\mathrm{R}$ Squared is used to help determine which model is the best. This model is significant $(F=97.180, p<0.001)$. The $F$ statistic is the regression mean square (MSR) divided by the residual mean square (MSE). If the significant value of the $\mathrm{F}$ statistic is small (smaller than say 0.05) then the independent variables do a good job explaining the variation in the dependent variable. The multiple correlation coefficients, $\mathrm{R}$, are the correlation between the observed and predicted values of the dependent variable. The value of $\mathrm{R}$ for regression models was produced by the regression procedure range from 0 to 1 . Larger values of $R$ indicate stronger relationships. Adjusted $R$ squared attempts to correct $\mathrm{R}$ squared to accurately reflect the goodness of fitness of the model in the population. We transformed the data to $\mathrm{z}$ scores prior to regression analysis, and then would get the beta coefficients as our unstandardized coefficients.

Hypothesis 1: The Relationship between Service Quality and Customer Satisfaction.

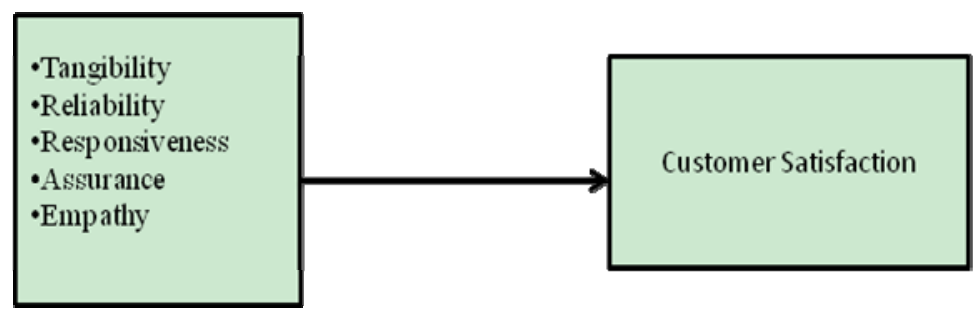

Figure 2. Effects of service quality and customer satisfaction 
The hypothesis testing that looks for direct relationship between tourism service quality and customer satisfaction is shown in Table 1 Tangibility $(\beta=.251, \mathrm{p}<0.001 ; \mathrm{t}$-value $=5.813)$, reliability $(\beta=.221, \mathrm{p}<0.001$; $\mathrm{t}$-value $=4.983)$, responsiveness $(\beta=.135, \mathrm{p}<0.01 ; \mathrm{t}$-value $=2.867)$, and assurance $(\beta=.309, \mathrm{p}<0.001$; $\mathrm{t}$-value $=6.480$ ) were found significant effects to DV. However, empathy was not found to be significant with customer satisfaction $(\beta=.088, \mathrm{p}>0.05 ; \mathrm{t}-\mathrm{value}=1.957)$.

Table 1. Regression results on tourism service quality and customer satisfaction

\begin{tabular}{llllll}
\hline Variable & \multicolumn{2}{l}{ Model 1 Remark } \\
Service Quality & Beta & t-test & Sig & VIF & \\
\hline Tangibility & $.251^{* * *}$ & 5.813 & .000 & 1.496 & Supported \\
Reliability & $.221^{* * *}$ & 4.983 & .000 & 1.579 & Supported \\
Responsiveness & $.135^{* *}$ & 2.867 & .004 & 1.784 & Supported \\
Assurance & $.309^{* * *}$ & 6.480 & .000 & 1.823 & Supported \\
Empathy & .088 & 1.957 & .051 & 1.628 & Not Supported \\
R2 & .607 & & & & \\
Adjusted R2 & .600 & & & & \\
F Value & 97.180 & & & & \\
Sig. F & .000 & & & & \\
\hline
\end{tabular}

Note: ${ }^{*} \mathrm{p}<0.05 ; * * \mathrm{p}<0.01 ; * * * \mathrm{p}<0.001$.

Hypothesis 2: The Relationship between Service Quality and Customer Loyalty.

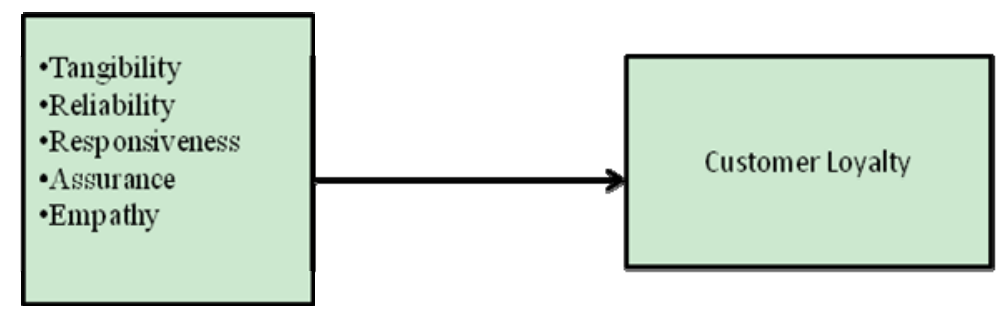

Figure 3. Effects of service quality and customer loyalty

The independent variable is tourism service quality can elucidate $56 \%(\mathrm{R} 2=.56)$ of variance towards customer loyalty. The $44 \%$ due to error by other factors is not included in this study. This model is significant $(\mathrm{F}=80.942$, $\mathrm{p}<0.001)$. In fact, the hypothesis testing shows in Table 2 that tangibility $(\beta=.413, \mathrm{p}<0.001$; $\mathrm{t}$-value $=9.062)$, reliability $(\beta=.162, \mathrm{p}<0.01$; t-value $=3.437)$, responsiveness $(\beta=.099, \mathrm{p}<0.05$; $\mathrm{t}$-value $=1.991)$ and empathy $(\beta=.219, \mathrm{p}<0.01 ; \mathrm{t}$-value $=4.605)$ were found positively significant to customer loyalty. Nevertheless, assurance $(\beta=.072, \mathrm{p}>0.05$; t-value $=1.431)$ was found not significant with customer loyalty.

Hypothesis 3: The Relationship between Customer Satisfaction and Customer Loyalty

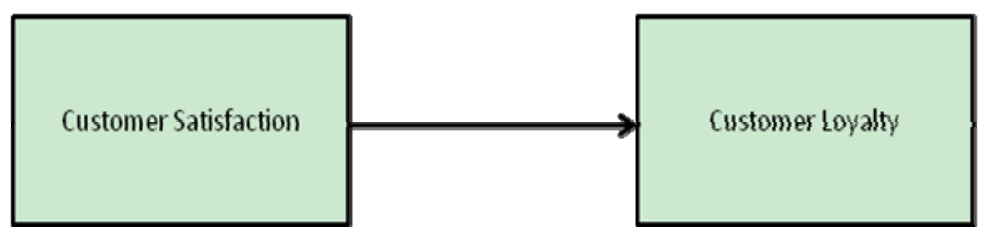

Figure 4. Effects of customer satisfaction and customer loyalty 
Table 2. Regression results on tourism service quality and customer loyalty

\begin{tabular}{llllll}
\hline Variable & \multicolumn{2}{l}{ Model 1 Remark } \\
Service Quality & Beta & t-test & Sig & VIF & \\
\hline Tangibility & $.413^{* * *}$ & 9.062 & .000 & 1.489 & Supported \\
Reliability & $.162^{* *}$ & 3.437 & .001 & 1.597 & Supported \\
Responsiveness & $.099^{*}$ & 1.991 & .047 & 1.771 & Supported \\
Assurance & .072 & 1.431 & .154 & 1.808 & Not Supported \\
Empathy & $.219^{* * *}$ & 4.605 & .000 & 1.621 & Supported \\
R2 & .564 & & & & \\
Adjusted R2 & .557 & & & & \\
F Value & 80.942 & & & & \\
Sig. F & .000 & & & & \\
\hline Note: $* \mathrm{p}<0.05 ; * *<0.01 * * * *<0.001$. & & & &
\end{tabular}

Note: ${ }^{*} \mathrm{p}<0.05 ; * * \mathrm{p}<0.01 ; * * * \mathrm{p}<0.001$.

Table 3 presents the results of regression analysis for customer satisfaction and customer loyalty. The goodness of the model is 41 percent and significant $(\mathrm{F}=225.919, \mathrm{p}<0.001)$. The hypothesis testing in Table 3 shows customer satisfaction was positively significant with customer loyalty $(\beta=0.647, \mathrm{p}<0.001 ; \mathrm{t}$-value $=15.031)$.

Table 3. Regression results on customer satisfaction and customer loyalty

\begin{tabular}{llllll}
\hline Variable & \multicolumn{2}{l}{ Model 1 } & & & Remark \\
Customer satisfaction & Beta & t-test & Sig & VIF & \\
\hline Customer loyalty & $.647^{* * *}$ & 15.031 & .000 & 1.000 & Supported \\
R2 & .419 & & & \\
Adjusted R2 & .417 & & & \\
F Value & 225.919 & & & \\
Sig. F & .000 & & & \\
\hline
\end{tabular}

Note: ${ }^{*} \mathrm{p}<0.05 ; * * \mathrm{p}<0.01 ; * * * \mathrm{p}<0.001$.

\subsection{Multiple Regression Analysis}

The purpose of multiple regressions is to answer the last main hypothesis. However, customer satisfaction was treated as a mediator to the extent to which it carries the influences of service quality to customer loyalty as shown in the figure 4. Thus, Baron and Kenny (1986) theory was applied to explore a mediating effect. 
Pah a

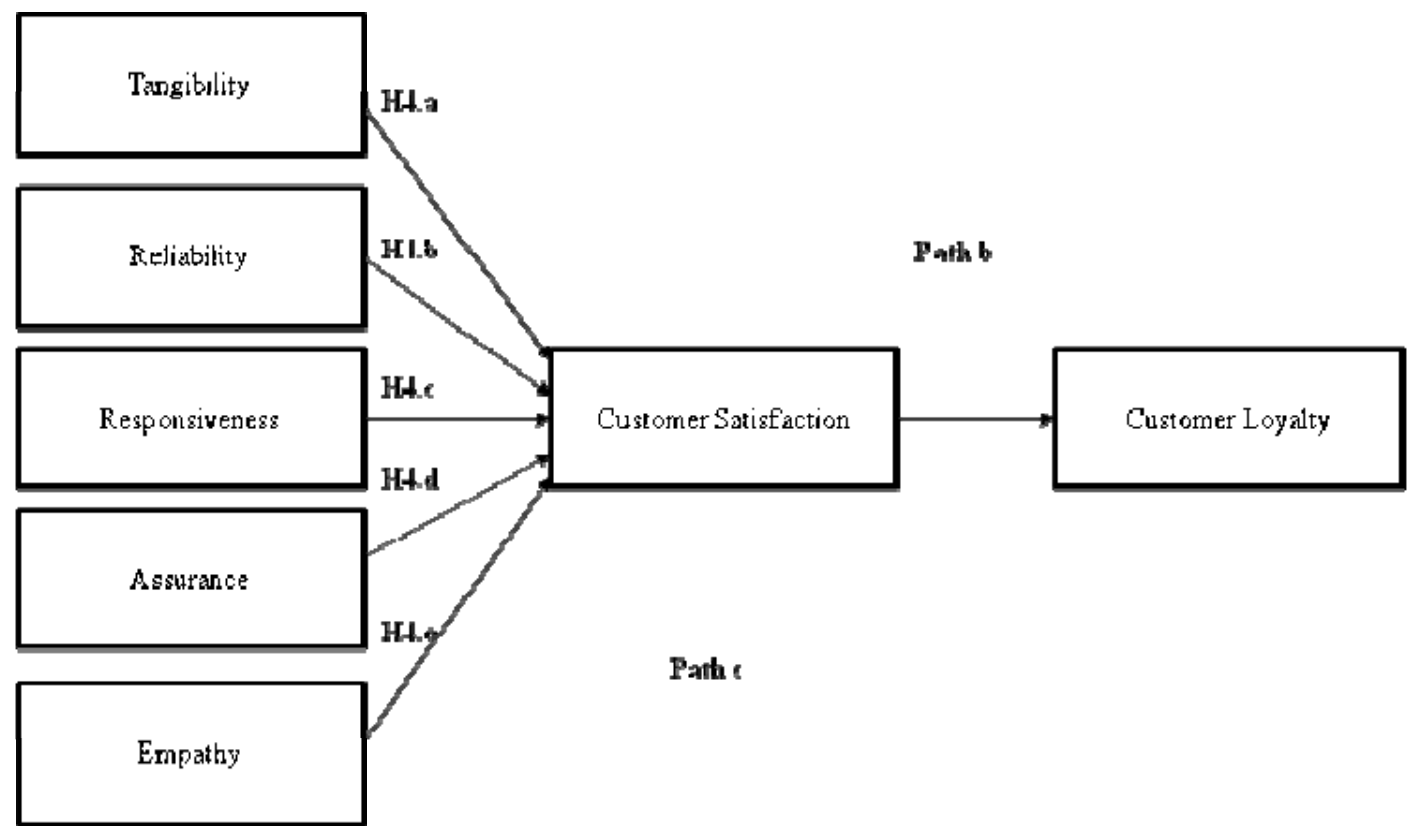

Figure 5. The mediation of customer satisfaction on the relationship between tourism service quality and customer loyalty

Table 4. Multiple regression results of tourism service quality, customer satisfaction and customer loyalty

\begin{tabular}{|c|c|c|c|c|c|c|c|c|c|c|c|}
\hline \multirow{4}{*}{ Predictor } & \multicolumn{2}{|c|}{ Model 1} & \multicolumn{2}{|c|}{ Model 2} & \multicolumn{2}{|c|}{ Model 3} & \multicolumn{5}{|c|}{ Model 4} \\
\hline & \multirow{3}{*}{ t-test } & \multicolumn{2}{|l|}{ Standardized } & \multicolumn{2}{|l|}{ Standardized } & \multicolumn{2}{|l|}{ Standardized } & \multicolumn{2}{|l|}{ Standardized } & \multirow{3}{*}{ VIF } & \multirow{3}{*}{ Remark } \\
\hline & & Coefficients & t-test & Coefficients & t-test & Coefficients & t-test & Coefficients & Sig & & \\
\hline & & $\beta$ & & $\beta$ & & $\beta$ & & $\beta$ & & & \\
\hline Constant & & & & & & & 1.244 & & & & \\
\hline Tangibility & 5.813 & $.251 * * *$ & 9.062 & $.413 * * *$ & & & 7.095 & $.335 * * *$ & .000 & 1.580 & $\begin{array}{l}\text { Partial } \\
\text { mediate }\end{array}$ \\
\hline Reliability & 4.983 & $.221 * * *$ & 3.437 & $.162 * *$ & & & 1.932 & .095 & .054 & 1.710 & $\begin{array}{l}\text { Full } \\
\text { mediate }\end{array}$ \\
\hline Responsiveness & 2.867 & $.135 * *$ & 1.991 & $.099 *$ & & & 1.480 & .073 & .140 & 1.741 & $\begin{array}{l}\text { Full } \\
\text { mediate }\end{array}$ \\
\hline Assurance & 6.480 & $.309 * * *$ & 1.431 & .072 & & & & & & & \\
\hline Empathy & 1.957 & .088 & 4.605 & $.219 * * *$ & & & & & & & \\
\hline $\begin{array}{l}\text { Customer } \\
\text { satisfaction }\end{array}$ & & & & & 15.031 & $.647 * * *$ & 4.641 & $.274 * * *$ & .000 & 2.460 & $\begin{array}{l}\text { Partial } \\
\text { mediate }\end{array}$ \\
\hline $\mathrm{F}$ & 97.180 & & 80.942 & & 225.91 & & 66.665 & & & & \\
\hline $\mathrm{R}^{2}$ & .607 & & .564 & & .419 & & .565 & & & & \\
\hline Adjusted $\mathrm{R}^{2}$ & .600 & & .557 & & .417 & & .556 & & & & \\
\hline $\mathrm{F}^{2}$ Change & 97.180 & & 80.942 & & 225.91 & & 66.665 & & & & \\
\hline
\end{tabular}

Note: ${ }^{*} \mathrm{p}<0.05, * * \mathrm{p}<0.01, * * * \mathrm{p}<0.001$. 
Table 4 shows the steps to identify the mediating effects. The first condition is the independent variable which is significantly associated with the customer satisfaction. Tangibility $(\beta=.251, \mathrm{p}<0.001 ; \mathrm{t}$-value $=5.813)$, reliability $(\beta=.221, \mathrm{p}<0.001$; t-value $=4.983)$, responsiveness $(\beta=.135, \mathrm{p}<0.01 ; \mathrm{t}$-value $=2.867)$, and assurance $(\beta=.309, \mathrm{p}<0.001 ; \mathrm{t}$-value $=6.480)$ were significant to customer satisfaction. Second condition is the independent variable which is significantly associated with the customer loyalty. Tangibility $(\beta=.413, \mathrm{p}<0.001$; $\mathrm{t}$-value $=9.062)$, reliability $(\beta=.162, \mathrm{p}<0.01$; $\mathrm{t}$-value $=3.437)$, responsiveness $(\beta=.099, \mathrm{p}<0.05$; $\mathrm{t}$-value $=$ $1.991)$ and empathy $(\beta=.219, \mathrm{p}<0.01$; t-value $=4.605)$ were found positively significant to customer loyalty. Next, the mediator variable is significantly associated with the dependent variable. Customer satisfaction was positively significant with customer loyalty $(\beta=0.647, \mathrm{p}<0.001$; $\mathrm{t}$-value $=15.031)$. Finally, when the independent variables namely; reliability and responsiveness and the mediator variable customer satisfaction are controlled, a previously significant relationship between the independent and dependent variable is no longer significant. Therefore, it can be interpreted that customer satisfaction fully mediates the relationship between reliability and responsiveness and customer loyalty. Hence, hypothesis H4.b and H4.c are accepted. On the other hand, the results revealed that there is a significant relationship between tangibility and customer loyalty when controlled by customer satisfaction. Therefore, it can be interpreted that customer satisfaction partially mediates the relationship between tangibility and customer loyalty. Hence, hypothesis H4.a is accepted.

\section{Conclusion}

In the preliminary stage of this study, a scale for measuring the service quality of three hotels which are branches of a five-star hotel chain was adapted from Parasuraman et al. (1985) SERVQUAL scale model. Generally the study has examined the relationship among service quality, customer satisfaction and customer loyalty. Specifically the study seeks to provide answers to four hypotheses: the relationship between service quality and customer satisfaction; the relationship between service quality and customer loyalty; and the relationship between customer satisfaction and the customer loyalty and customer satisfaction mediates the effect of service quality on customer loyalty. It is hoped that the knowledge derived from this study will be of great assistance to hotel managers in further improving their hotels.

However, it is not sufficient to be knowledgeable in the areas of service quality only, customer satisfaction and customer loyalty is definitely an added advantage that is capable of helping hotel managers to meet the challenges of improving service quality in the hotel industry. In fact, the issue of observing customer satisfaction has become an important one in the hotel industry. The failure to recognize the power of customer satisfaction, especially their emotions, may cause damage the power of customer retention and loyalty (Yi \& Alison, 2001). Therefore, the hotel management's greatest challenge lies in attracting customers as well as identifying their satisfaction individually.

Managers have also come to understand that building and retaining customer loyalty has become a strategic business strategy and not just a marketing program which can help to enhance sales for a certain period. Seen in this light, the need to enhance customer loyalty and maximize the market share of customers in the hotel sector is a success pair indeed. In order to maintain customer market share, it is important to follow up on their loyalty persistently. The presence of clear guidelines to improve loyalty-marketing approaches in any given industry is a great advantage to hotel managers. Therefore, a thorough understanding of the background and the factors leading to customer loyalty can help hotel managers develop strategies that enable them to remain competitive in the hotel industry.

The present research contributes to the theoretical orientation of TSQ and literature related to tourists' satisfaction in the hotel industry by defining some central and important levels of service quality. This research also identifies five TSQ dimensions: tangibility, reliability, responsiveness, assurance and empathy. These dimensions encompass the criteria which were used by tourists participating in the study for the purpose of evaluating the service quality of the three five-star hotels in Jordan. The findings of this study indicate that assurance is the most important factor in predicting TSQ evaluation. It is followed by tangibility, reliability and responsiveness. The findings also suggest that assurance has emerged as the best predictor of TSQ of the five dimensions of service quality. In addition, the findings of this study lend support to the idea that the SERVQUAL scale should be adapted for the service environment.

\section{References}

Andreas, E., \& Wolfgang, U. (2002). Customer perceived value: a substitute for satisfaction in business markets? Journal of Business \& Industrial Marketing, 17(2-3), 107-118.

Al-Rousan, R., Badaruddin, M. (2010). Customer loyalty and the impacts of service quality: the case of five star hotels in jordan. International Journal of Business,Economics, Finance and Management Sciences, 3(2), 
202-208.

Akbaba, A. (2006). Measuring service quality in the hotel industry: A study in a business hotel in Turkey. International Journal of Hospitality Management, $25(2), \quad$ 170-192. http://dx.doi.org/10.1016/j.ijhm.2005.08.006

Barsky, J., \& Labagh, R. (1992). A strategey for customer satisfaction. Cornell Hotel and Restaurant Administration Quarterly, 33(5), 32-40. http://dx.doi.org/10.1016/0010-8804(92)90025-Z

Baloglu, S. (2002). Dimensions of customer loyalty: separating friends from well wishers. Cornell Hotel and Restaurant Administration Quarterly, 43(1), 47-59. http://dx.doi.org/10.1016/S0010-8804(02)80008-8

Bitner, M. J., \& Hubbert, A. R. (1994). Encounter satisfaction versus overall satisfaction versus quality. Service Quality: New Directions in Theory and Practice (pp. 72-94). Thousand Oaks, CA: Sage Publications. http://dx.doi.org/10.4135/9781452229102.n3

Boulding, W., Kalra, A., Staelin, R., \& Zeithaml, V. A. (1993). A dynamic process model of service quality: from expectations to behavioral intentions. Journal of Marketing Research, 30(1), 7-27. http://dx.doi.org/10.2307/3172510

Bowen, J., \& Shoemaker, S. (1998). Loyalty: a strategic commitment. Cornell Hotel and Restaurant Administration Quarterly, 39(1), 12-25. http://dx.doi.org/10.1177/001088049803900104

Bowen, J., \& Chen, S. (2001). The relationship between customer loyalty and customer satisfaction. International Journal of Contemporary Hospitality Management, 21(3), 213-217. http://dx.doi.org/10.1108/09596110110395893

Briggs, S., Sutherland, J., \& Drummond, S. (2007). Are hotels serving quality? An exploratory study of service quality in the Scottish hotel sector. Tourism Management, 28(4), 1006-1019. http://dx.doi.org/10.1016/j.tourman.2006.08.015

Callan, R. J., \& Bowman, L. (2000). Selecting a hotel and determining salient quality attributes: a preliminary study of mature British travellers. International Journal of Tourism Research, 2(2), 97-118. http://dx.doi.org/10.1002/(SICI)1522-1970(200003/04)2:2<97::AID-JTR190>3.0.CO;2-1

Callan, R. J., \& Kyndt, G. (2001). Business travellers' perception of service quality: a prefatory study of two European city centre hotels. International Journal of Tourism Research, 3(4), 313-323. http://dx.doi.org/10.1002/jtr.333

Caruana, A., Money, A. H., \& Berthon, P. R. (2000). Service quality and satisfaction-the moderating role of $\begin{array}{llll}\text { value. European Journal of } & \text { Marketing, 34(11/12), }\end{array}$ http://dx.doi.org/10.1108/03090560010764432

Caruana, A. (2002). Service loyalty. European Journal of Marketing, 36(7/8), 811-828. http://dx.doi.org/10.1108/03090560210430818

Chen McCain, S. L, Jang, S. C, \& Hu, C. (2005). Service quality gap analysis toward customer loyalty: practical guidelines for casino hotels. International Journal of Hospitality Management, 24(3), 465-472. http://dx.doi.org/10.1016/j.ijhm.2004.09.005

Choi, T. Y., \& Chu, R. (2001). Determinants of hotel guests' satisfaction and repeat patronage in the Hong Kong hotel industry. International Journal of Hospitality Management, 20(3), 277-297. http://dx.doi.org/10.1016/S0278-4319(01)00006-8

Choi, T., \& Chu, R. (2000). Levels of satisfaction among Asian and Western travellers. International Journal of Quality and Reliability Management, 17(2), 116-131. http://dx.doi.org/10.1108/02656710010304537

Cronin, J. J., \& Taylor, S. A. (1992). Measuring service quality: a reexamination and extension. The Journal of Marketing, 56(3), 55-68. http://dx.doi.org/10.2307/1252296

Davis, F. W., \& Mandrodt, K. B. (1996). Customer-responsive management: the flexible advantage. Blackwell: Cambridge.

Dube, L., \& Renaghan, L. M. (1999). Sustaining competitive advantage. Cornell Hotel and Restaurant Administration Quarterly, 40, 27-33. http://dx.doi.org/10.1016/S0010-8804(99)80236-5

Finn, A. (2005). Reassessing the foundations of customer delight. Journal of Service Research, 8(2), 103-116. http://dx.doi.org/10.1177/1094670505279340

Flynn, B. B., Sakakibara, S., \& Schroeder, R. G. (1995). Relationship Between Jit And Tqm: Practices And 
Performance. Academy of Management Journal, 38(5), 1325-1360. http://dx.doi.org/10.2307/256860

Fornell, C., Johnson, M. D., Anderson, E.W., Cha, J., \& Bryant, B. (1996). The American customer satisfaction index: description, findings, and implications. Journal of Marketing, 60(4), 7-18. http://dx.doi.org/10.2307/1251898

Getty, J. M., \& Thompson, K. N. (1994). A procedure for scaling perceptions of lodging quality. Hospitality Research Journal, 18, 75-96.

Gunderson, M., Heide, M., \& Olsson, U. (1996). Hotel guest satisfaction among business travelers: What are the important factors? Cornell Hotel and Restaurant Administration Quarterly, 37(2), 72-79. http://dx.doi.org/10.1016/0010-8804(96)83104-1

Heskett, J. L., Sasser, W. E., \& Schlesinger, L. A. (1997). The service profit chain: How leading companies link profit and growth to loyalty, satisfaction, and value. Free Press.

Hudson, S., Hudson, P., \& Miller, G. A. (2004). The measurement of service quality in the tour operating sector: a methodological comparison. Journal of Travel Research, 42(3), 305. http://dx.doi.org/10.1177/0047287503258839

Hutchinson, J., Lai, F., \& Wang, Y (2009). Understanding the relationships of quality, value, equity, satisfaction, and behavioral intentions among golf travelers. Tourism Management Journal, 30(2), 298-308. http://dx.doi.org/10.1016/j.tourman.2008.07.010

Javalgi, R. R., \& Moberg, C. R. (1997). Service loyalty: implications for service providers. Journal of Services Marketing, 11(3), 165-179. http://dx.doi.org/10.1108/08876049710168663

Jones, T. O., \& Sasser, J. R. (1995). Why satisfied customers defect. Harvard Business Review, 73, 88-99.

Kandampully, J., \& Suhartanto, D. (2003). The role of customer satisfaction and image in gaining customer loyalty in the hotel industry. Journal of Hospitality \& Leisure Marketing, 10(1/2), 3-25. http://dx.doi.org/10.1300/J150v10n01_02

Kandampully, J., \& Suhartanto, D. (2000). Customer loyalty in the hotel industry: the role of customer satisfaction and image. International Journal of Contemporary Hospitality Management, 12, 346-351. http://dx.doi.org/10.1108/09596110010342559

Lewis, B. R., \& McCann, P. (2004). Service failure and recovery: evidence from the hotel industry. International $\begin{array}{lllll}\text { Journal of Contemporary Hospitality } & \text { Management, }\end{array}$ http://dx.doi.org/10.1108/09596110410516516

Luck, D., \& Lancaster, G. (2003). E-CRM: customer relationship marketing in the hotel industry. Managerial Auditing Journal, 18(3), 213-231. http://dx.doi.org/10.1108/02686900310469961

Maltz, A., \& Maltz, E. (1998). Customer service in the distribution channel: empirical findings. Journal of Business Logistics, 19(2), 103-130.

Mentzer, J. T., Flint, D. J., \& Hult, G. T. M. (2001). Logistics service quality as a segment-customized process. The Journal of Marketing, 65(4), 82-104. http://dx.doi.org/10.1509/jmkg.65.4.82.18390

Morgan, R. M., \& Hunt, S. D. (1994). The commitment-trust theory of relationship marketing. The Journal of Marketing, 58(3), 20-38. http://dx.doi.org/10.2307/1252308

Oh, H. (2000). Diners' perceptions of quality, value, and satisfaction: A practical viewpoint. Cornell Hotel and Restaurant Administration Quarterly, 41, 58-66. http://dx.doi.org/10.1177/001088040004100317

Oliva, T. A., Oliver, R. L., \& MacMillan, I. C. (1992). A catastrophe model for developing service satisfaction strategies. The Journal of Marketing, 56(3), 83-95. http://dx.doi.org/10.2307/1252298

Oliver, R. L. (1997). Satisfaction: A Behavioral Perspective on the Consumer. McGraw-Hill.

Parasuraman, A., Zeithaml, V. A., \& Berry, L. L. (1985). A Conceptual model of service quality and its implications for future research. Journal of Marketing, 49(4), 41-50. http://dx.doi.org/10.2307/1251430

Parasuraman, A., Zeithaml, V. A., \& Berry, L. L. (1988). SERVQUAL: A multiple-item scale for measuring consumer perceptions of service quality. Journal of Retailing, 64(1), 5-6.

Parasuraman, A., Zeithaml, V. A., \& Berry, L. L. (1994). Reassessment of expectations as a comparison standard in measuring service quality: implications for further research. The Journal of Marketing, 111-124. http://dx.doi.org/10.2307/1252255 
Ruyter, D., Bloemerb, J., \& Peetersa, P (1997). Merging service quality and service satisfaction. An empirical test of an integrative model. Journal of Economic Psychology, 18(4), 387-406. http://dx.doi.org/10.1016/S0167-4870(97)00014-7

Saleh, K., \& Rayan, K. (1991). Analysing Service Quality in the Hospitality Industry Using the SERVQUAL Model. The Service Industries Journal, 11(3), 324-345. http://dx.doi.org/10.1080/02642069100000049

Slattery, P. (2003). Finding the hospitality industry. Journal of Hospitality, Leisure, Sport and Tourism Education, 2(1), 119-120. http://dx.doi.org/10.3794/johlste.21.40

Sivadas, E., \& Baker-Prewitt, J. L. (2000). An examination of the relationship between service quality, customer satisfaction, and store loyalty. International Journal of Retail \& Distribution Management, 28(2), 73-82. http://dx.doi.org/10.1108/09590550010315223

Skogland, I., \& Siguaw, J. A. (2004). Are your satisfied customers loyal? Cornell Hotel and Restaurant Administration Quarterly, 45(3), 221-235. http://dx.doi.org/10.1177/0010880404265231

Sekaran, U. (2003). Research methods for business: A skill building approach (4th ed.). New York: John Wiley $\&$ Sons.

Torres, E. N., \& Kline, S. (2006). From satisfaction to delight: a model for the hotel industry. International Journal of Contemporary Hospitality Management, 18(4), 290-301. http://dx.doi.org/10.1108/09596110610665302

Tsang, N., \& Qu, H. (2000). Service quality in China's hotel industry: a perspective from tourists and hotel managers. International Journal of Contemporary Hospitality Management, 12(5), 316-326. http://dx.doi.org/10.1108/09596110010339706

Tsaur, S. H., \& Lin, Y. C. (2004). Promoting service quality in tourist hotels: The role of HRM practices and service behavior. Tourism Management, 25(4), 471-481. http://dx.doi.org/10.1016/S0261-5177(03)00117-1

Tepeci, M. (1999). Increasing brand loyalty in the hospitality industry. International Journal of Contemporary Hospitality Management, 11, 223-229. http://dx.doi.org/10.1108/09596119910272757

Wilkins, H., Merrilees, B., \& Herington, C. (2007). Towards an understanding of total service quality in hotels. $\begin{array}{llll}\text { International Journal of Hospitality } & \text { Management, }\end{array}$ http://dx.doi.org/10.1016/j.ijhm.2006.07.006

Yu, Y. T., \& Alison, D. (2001). The contribution of emotional satisfaction to consumer loyalty. International Journal of Service Industry Management, 12(3), 234-250. http://dx.doi.org/10.1108/09564230110393239

Zeithaml, V. A .(1988). Consumer perceptions of price, quality, and value: a means-end model and synthesis of evidence. The Journal of Marketing, 52(3), 2-22. http://dx.doi.org/10.2307/1251446

Zeithaml, V. A., Berry, L. L., \& Parasuraman, A. (1996). The Behavioral Consequences of Service Quality. Journal of Marketing, 60(2), 31-46. http://dx.doi.org/10.2307/1251929

\section{Copyrights}

Copyright for this article is retained by the author(s), with first publication rights granted to the journal.

This is an open-access article distributed under the terms and conditions of the Creative Commons Attribution license (http://creativecommons.org/licenses/by/3.0/). 